\title{
Crowdsourcing and Behaviour of Participant in Social Media Marketing
}

\author{
Sosyal Medya Pazarlamada Kitle Kaynak ve Katılımcı Davranışı
}

\author{
Mehmet Etlioğlu*
}

\begin{abstract}
Web 2.0 technology, called the Internet and Social Web, has created a participatory cultural environment in the relations of individuals with each other and with organizations. Businesses use external resources, taking advantage of the collective intelligence and wisdom of online communities, as well as internal resources and professional collaborations in the process of solving problems or obtaining innovative ideas. Today, consumers have begun to be involved in all processes in businesses. The desire of consumers to be included in all the processes of the businesses, the desire of the businesses to learn the demands and needs of the consumers, and the inclusion of them in the innovation processes accelerated the transition to open innovation. The ideas, opinions, suggestions and content created by the masses created online in order to increase the participation of the masses in the management, to design innovative products or services and to solve the problems have become very important. Crowdsourcing in the value creation process provides benefits such as reducing new product development time, reducing innovation costs, increasing the acceptance of new products, and services in the market, and improving the consumer's subjective perception of innovation. However, in the value creation process, who will add value, how the audience will be determined, the size of the audience and motivation are important issues. In this study, the topics of crowdsourcing, open and user innovation, usergenerated content, consumer creativity, co-creative consumers, producing consumers and crowdsourcing user behaviors, and the contributions of crowdsourcing to the realization of problem solving processes and innovations of enterprises, and user behaviors are examined.
\end{abstract}

Keywords: Crowdsourcing, Crowdsourcing User Behavior, Social Media Marketing

Öz: İnternet ve Sosyal Web olarak adlandırılan Web 2.0 teknolojisi bireylerin birbirleriyle ve organizasyonlarla ilişkilerinde katılımcı bir kültür ortamı yaratmıştır. İşletmeler, sorunlarını çözme veya yenilikçi fikirlerin elde edilmesi sürecinde iç kaynaklar ve profesyonel iş birlikteliklerin yanı sıra çevrimiçi toplulukların kolektif zekâsından ve bilgeliklerinden yararlanarak dış kaynakları da kullanmaktadırlar. Günümüzde tüketiciler işletmelerdeki bütün süreçlere dahil olmaya başlamışlardır. Tüketicilerin işletmelerin tüm süreçlerine dahil olma istekleri, işletmelerin ise, tüketicilerin istek ve ihtiyaçlarını öğrenmek istemeleri, onları yenilikçilik süreçlerine dahil etmeleri açık inovasyona geçişi hızlandırmıştır. Kitlelerin yönetime katılımını artırmak, yenilikçi ürün veya hizmetler tasarlamak ve sorunları çözmek amacıyla çevrimiçi oluşturulan kitlelerin fikir, görüş, önerileri ve oluşturdukları içerikler çok önemli hale gelmiştir. Değer yaratma sürecinde kitle kaynak kullanımı, yeni ürün geliştirme süresinin azaltılması, inovasyon maliyetlerinin azaltılması, yeni ürün ile hizmetlerin pazarda kabulünün artması ve tüketicinin sübjektif yenilik algısının iyileştirilmesi gibi faydalar sağlamaktadır. Ancak,

\footnotetext{
* Dr, OSTİM Teknik Üniversitesi, İktisadi ve İdari Bilimler Fakültesi, Pazarlama Bölümü ORCID: 0000-0001-5341-5777, mehmet.etlioglu@ ostimteknik.edu.tr

Received/Geliş: 30 September/Eylül 2021

Accepted/Kabul: 23 November/Kasim 2021

Düzeltme/Revised form: 20 November/Kasım 2021

Published/Yayın: 25 December/Aralık 2021
}

e-ISSN: 2149-4622. (C) 2013-2021 Muş Alparslan Üniversitesi. TÜBİTAK ULAKBİM DergiPark ev sahipliğinde. Her hakk1 saklıdır. http://dx.doi.org/10.18506/anemon.1003058 
değer yaratma sürecinde kimlerin değer katacağı, kitlenin nasıl belirleneceği, kitlenin büyüklüğü ve motivasyon konuları önemli konular olarak karşımıza çıkmaktadır. Bu çalışmada kitle kaynak kullanımı, açık ve kullanıcı inovasyonu, kullanıcı tarafından oluşturulan içerikler, tüketici yaratıcılığı, ortak yaratıcı tüketiciler, üreten tüketiciler ve kitle kaynak kullanıcı davranışları konuları ile kitle kaynak kullanımının işletmelerin problem çözme süreçleri ve inovasyonlarının gerçekleştirmelerine katkıları ve kullanıcı davranışları ele alınmıştır.

Anahtar Kelimeler: Kitle Kaynak, Kitle Kaynak Kullanıcı Davranışı, Sosyal Medya Pazarlama

\section{Introduction}

Nowadays, the network structure that emerged as a result of the developments in the internet and web technologies has offered individuals the opportunity to easily access information, communicate with each other, make comments, create a community, and share by producing content. Social media channels that emerged as a result of developments in web technologies offer great opportunities for individuals to carry out these activities. Creative individuals, who have the opportunity to access the tools where they can realize their innovative ideas, can implement their ideas and share these activities on social media. Recognizing the creativity in individuals, businesses seek ways to include individuals or the crowd they create in all their processes in order to realize the innovations they need or to solve any problems or issues. Organizations can develop or innovate their products and services by receiving the ideas, opinions, and suggestions of the crowds they have determined and created through social media. Social media channels make a great contribution to the realization of sustainable relations and interactions with stakeholders in the ecosystems of businesses. In an intensely competitive environment, businesses must differentiate from their competitors in order to be permanent and sustainable. The most important dimension of this differentiation is innovations. Businesses can obtain the needed services, ideas or content on social media with the contributions of communities. Businesses use social media for market research, direct communication with customers, sales and promotions or e-commerce. In addition, businesses use social media channels effectively and efficiently in order to benefit from the wisdom and experience of the masses in the creation of new products and services and the realization of innovations. In a sense, this shows that users are both producers and consumers with the content they produce. In this context, the participatory culture of social media and its ability to spread very quickly offer great advantages to businesses in terms of crowdsourcing by increasing the participation potential of more audiences. In this context, crowdsourcing has emerged which is also expressed as digital collaboration, social production, participatory culture, common intelligence or collective intelligence, the wisdom of the crowd and community resource use. With the use of crowdsourcing, which is the result of the sharing culture, organizations involve the masses in the innovation / product development processes with a set of tools (user tools) they offer by benefiting from the wisdom and collective intelligence of the crowds. With this practice defined as mass customization, the role of customers has evolved beyond being a consumer into co-creators (Büyükpilavc1, 2014: 1) and prosumers. Businesses have made them both producers and consumers by taking advantage of the wisdom, innovation and creativity of consumers in all production processes. However, the selection of crowds created online, determining their size and motivation issues also emerge as important problems. In the success of crowdsourcing, a willing, active and motivated crowd, transparency and trust of participants, and not manipulating crowdsourcing practices or using participatory culture as exploitation play an important role. In the study, the topics related to crowdsourcing in social media, innovation, user-generated content, consumer creativity, co-creator, prosumer, wisdom of crowd, collective intelligence and crowdsourcing participant behaviors were examined. The importance of crowdsourcing in problem solving, innovations and new product development processes was emphasized in the value creation process of businesses. It is considered that the selection of the audience related to the participants, its size, the motivation of the crowd, transparency and the trust of the participants in the crowdsourcing of the businesses will contribute to the literature as the most important issues to be considered in the success of the crowdsourcing. 


\section{Social Web-Web 2.0- Social Media Marketing}

Internet has undoubtedly been an innovation that has been instrumental in shifting the power focus from marketers to consumers. Internet and mobile phone users and the increase in the use of digital content make digital marketing more popular. With the spread of the internet and the rapid development of information and communication technologies, consumers who want to be constantly informed about products/services and companies have had the opportunity to access a lot of data quickly and easily from anywhere and anytime. Consumers can establish two-way communication with other users, such as comparing products, reading price alternatives, comments, and obtaining information about product quality, satisfaction and companies with other users. Manufacturers also want to include their customers in the design of the products and post-marketing processes, learn their opinions, thoughts, and comments, create and share content by establishing a sustainable relationship with their customers. Content sharing by users also means a great transfer of information. Understanding the ease with which customers can procure and purchase products from anywhere in the world, with the Internet facilitating globalization, marketers have become stronger by strategically positioning themselves wherever their customers are in the digital space. Social media and social networking websites constitute the most modern basis of marketing communication (Conrad et al., 2010). Kabani and Brogan (2010) state that social media helps businesses market their brands to the broader global community. In this context, a marketing approach has emerged that includes its customers in its processes, listens to their ideas, thoughts and comments about products and services and allows them to make innovations, collects and analyzes enriched and personalized data, and produces solutions as a result of evaluations and constantly communicates with customers. The aim is to pave the way for innovation and creativity related to products and services by including the formed consumer mass in its processes. It is to convey the right message (content) to the right audiences at the right time, through the right media. Marketers want them to become omnichannel publishers by informing the target audience who are constantly looking for information or by creating audiences of individuals with ideas, opinions and suggestions, involving them in product development and innovation processes, and encouraging consumers to create content.

Web 2.0 enables consumers to create content by providing the necessary technical infrastructure for the media to be social. The main difference between social media and creative consumers is; while social media focuses on content, creative consumers are those who create this content. Web 2.0 has had three effects. Firstly; users' activities have shifted from the desktop to the web. Secondly; the focus of power has shifted from businesses to the masses through social media. Finally; value production has shifted from businesses to consumers through to creative consumers (Berthon et al., 2012: 262). Web 2.0 can be expressed as a set of technological innovations that facilitate chepaer content creation, interaction, and interoperability in terms of both hardware and software, and put the user at the center in terms of design, collaboration, and community building on the Web. Social media is a platform that offers various usage areas such as blogs, micro blogs, social networks, social bookmarks, podcasts, wikis, video sharing sites, and forums. These formats help people to share information and content with each other and thus provide users with the opportunity to reach the content they are looking for and interested in (Kılıç, 2015: 49-50). Web 2.0 started the revolutionary process that allows users to create and share content without their technical knowledge. In this context, users are actively involved in the process and have the ability to make any changes they want with the content and messages they create.

In the context of marketing, social media is considered as platforms where people form networks and share information and/or emotions (Kaplan and Haenlein, 2010). Social media marketing is a process that allows people to promote their products and services through electronic social media and to communicate and interact with large audiences that have not been reached through traditional communication channels (Weinberg, 2009: 3). Social media has created three fundamental changes in the market due to its dynamic, interconnected, egalitarian, and interactive features (Peters et al., 2013: 281). First, social media has enabled businesses and customers to connect with each other through a variety of platforms such as social networking sites (Facebook), microblogging sites (Twitter), and content communities (YouTube) (Kaplan and Haenlein, 2010). Second, social media 
has changed the way firms and customers interact and influence each other. This social interaction includes "actions" that affect the choices and consumption behaviors of others through communication or passive observation (Chen et al., 2011). These types of social interactions are referred to as "word of mouth (WOM) effects" or "contagion effects" (Nair et al. 2010). Third, due to the measurability feature of social media, the easy acquisition of data has facilitated the development of more customer relations with the ease of decision-making and product / service development processes of businesses (Libai et al., 2010).

Along with digital data, social media data is characterized by $3 \mathrm{~V}$ (volume, variety and velocity), volume, variety and speed, which refers to large amounts of data, various data sources and extensive real-time data (Alharthi et al., 2017). In addition to these, being secure and verifiable (verification) and having a meaningful value (value) also constitute the $5 \mathrm{~V}$ dimensions of big data. In addition, the analytics of data on social media platforms offers great advantages in sustainable social media marketing of businesses. Large amounts of social media data obtained from social networks, blogs, and forums in various formats (text, video, image) can now be easily extracted by various analytical methods and used by businesses (Moe and Schweidel, 2017). Therefore, social media data is an important resource for customer analysis, market research and crowdsourcing of new ideas, as well as a strategic resource that can improve marketing results to create value through social media data (Gnizy, 2019). Businesses have increasingly started to use social media tools in order to establish sustainable communication with customers, to acquire potential customers, to give confidence to their customers, to protect their brand awareness and image, and to benefit from the collective intelligence and innovative ideas of the target audience they have determined. Social networks take place as a unique supporting element in the transmission and dissemination of marketing messages, product presentations, and managing brand images (Alan et al., 2018: 497). In addition, it offers great advantages to consumers in terms of accessibility and ease of purchase anytime and anywhere, collecting and comparing information about products and services, learning comments, interactive and speed. On the other hand, it offers advantages to businesses in terms of being low cost, interactive, personalized, measurable, providing access to a very wide geography, following the target audience and being very open to creativity (Altınbaşak and Karaca, 2009: 468).

\section{Crowdsourcing}

The term crowdsourcing; it is a combination of the words "crowd" meaning "mass" and "out source" meaning outsourcing and means that an institution gets the resource it needs from the crowd (Seker, 2015). Crowdsourcing was used in the article "The Rise of Crowdsourcing" in Wired Magazine in June 2006 by Jeff Howe. He defines crowdsourcing as a company or institution making an open call to individuals through a network to complete a particular job (Howe, 2006). According to Gatautis and Vitkauskaite (2014), crowdsourcing is a type of participatory online activity which an individual, an institution, a non-profit organization, or a company offers to group members of diverse information and a diverse number of heterogeneous structures, to which they voluntarily undertake a task by flexible and open call. Crowdsourcing, as shown in Figure 1, consists of three components: audience (crowd), outsourcing and social web (Saxton, et al., 2013: 39). While crowdsourcing comes from a less specific, more public group, outsourcing is made from a specific, named group and involves a mix of bottom-up and top-down processes (Brabham, 2008b; Brabham, 2013; Prpić and Shukla, 2016).

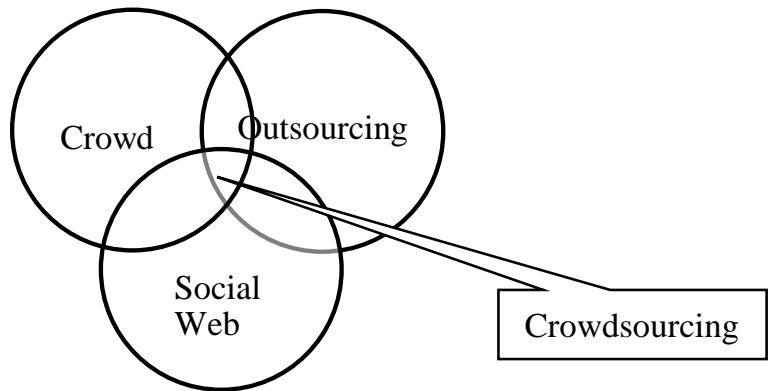

Figure 1: The Three Descriptors of Crowdsourcing

Source: Saxton, vd., (2013: 39) 
Crowdsourcing allows businesses to interact instantly and directly with consumers regarding information from sellers and distribution channels (Whitla, 2009). It provides benefits such as reducing the time required for new product development, reducing the cost of innovation, increasing the acceptance of new products and services in the market, and improving the consumer's subjective perception of innovation in terms of activating the consumers in the value creation process (Kleemann et al., 2008). It provides organizations with ways to learn about crowdsourcing methods such as "idea contests" or "innovation contests" provided by their employees" (LEGO Ideas). "Microtasks" performed by large paid crowds are another form of crowdsourcing (Amazon Mechanical Turk). In addition, "Wikipedia", an internet encyclopedia created with the contributions of everyone who entered the internet world in 2001, which is also used by non-profit organizations and to create common goods, can be given as an example. The impact of user communication and platform delivery should be considered when evaluating the performance of ideas in the context of crowdsourcing. (Tong et al., 2020). The classification of the type of crowdsourcing through the person/institution that has arisen is grouped under three headings in order to solve the problem; crowdsourcing initiatives made by public institutions, initiatives made by individuals and initiatives made by companies (Sánchez et al., 2015: 81-82). Howe (2008) identified the four main classes of crowdsourcing which led to the introduction of the concept of crowdsourcing to large masses as "collective intelligence", "crowdcreation", "crowdrating, or voting" and "crowdfunding". According to Arolas and Guevara (2012), there are eight basic elements in a crowdsourced venture. These elements are;

- A task with a clearly defined purpose,

- A clearly defined reward for the crowd,

- Clearly defined crowdsourcing provider,

- A clearly defined response to be received by the crowdsourcing provider,

- Online participation process,

- Open call for participation,

- Using Internet.

Whitla (2009)'s research on the use of crowdsourcing as a marketing innovation draws attention in three areas as advertising and promotion, product development and the market. Dawson and Bynghall (2011) identified the areas of crowdsourcing, content creation, idea generation, product development, customer insights, customer engagement, customer loyalty, and pricing. It also offers advantages such as reaching the masses with less cost (Gatautis and Vitkauskaite, 2014) and obtaining more qualified information by reaching expert personnel. Crowdsourcing offers many ways to get feedback very easily and cost-effectively. According to Palacios et al., (2016), crowdsourcing offers advantages in five areas such as problem solving, learning paradigms, open innovation, new product development, and enabling collaborative initiatives. Table 1 shows different areas related to crowdsourcing.

Table 1. Crowdsourcing Areas

\begin{tabular}{|l|l|}
\hline \multicolumn{1}{|c|}{ Writers } & \multicolumn{1}{|c|}{ Crowdsourcing Areas } \\
\hline Whitla, 2009. & $\begin{array}{l}\text { Advertising and Promotion, Product Development, } \\
\text { Market }\end{array}$ \\
\hline Dawson and Bynghall, 2011. & $\begin{array}{l}\text { Content Creation, Idea Generation, Product } \\
\text { Development, Customer Insights, Customer } \\
\text { Engagement, Customer Loyalty, Pricing }\end{array}$ \\
\hline Palacios et al., 2016. & $\begin{array}{l}\text { Problem Solving, Learning Paradigms, Open } \\
\text { Innovation, New Product Development, Enabling } \\
\text { Collaborative Initiatives. }\end{array}$ \\
\hline
\end{tabular}

According to Dawson and Bynghall (2011) the following are the success factors that are also important in crowdsourcing to a certain extent, such as participant characteristics, reputation measures, and project management to implement crowdsourcing models and services (Figure 2): 
Width of Contributors: The number or size of the pool is important as it forms the basis of resource use.

Quality of Contributors: The size of the pool may vary, but it is important that participants contribute their ideas, thoughts, and opinions with their qualities and qualities.

Public Reputation Measures: The most reliable and highest quality contributors are important for maintaining corporate talent and brand reputation.

Internal Reputation Measures: Because crowdsourcing deals with external business services, it is important to select the highest quality service providers that also require the appropriate skills and capacities for the business.

Project Management Capabilities: Crowdsourcing initiatives or specific marketing functions/actions require qualified and strong management capabilities as they will be executed as a project implementation.

Project Management Tools: It requires the use of certain tools, hardware and software in the crowdsourcing application.

Quality Control: Proper quality control procedures are needed as high quality results are expected in crowdsourcing.

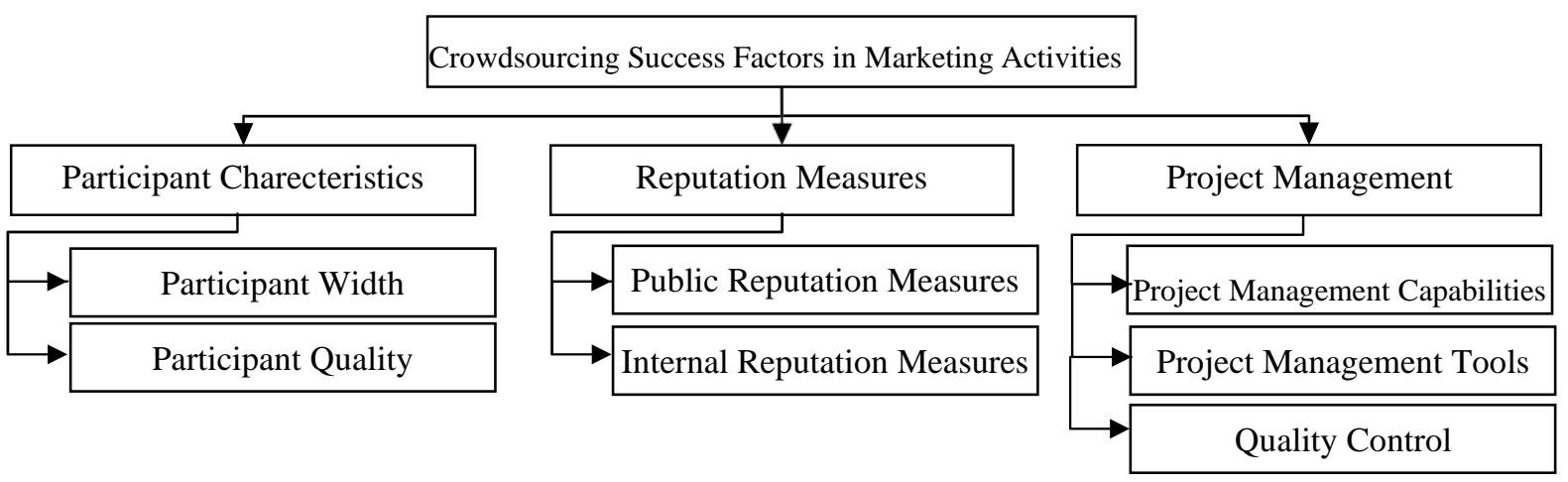

Figure 2: Crowdsourcing Success Factors in Marketing Activities

Source: Dawson ve Bynghall, (2011).

\subsection{User Innovation}

Today, innovations in information technologies, especially online tools, allow the increase of producer-consumer cooperation in the new product development process and these technologies are used by companies to involve users in the innovation process (İlter et al., 2016: 36). The first innovation in products is made by the users of the product, the suppliers of the product or the manufacturers of the product (Hippel, 2005). Prahalad and Ramaswamy (2000) stated that users have moved from their traditional role as consumers of the value created by companies to the role of cocreators. In this context, one of the most important sources that affect and direct the innovation decision process of enterprises is users, in other words, consumers. The demands of consumers in the market are constantly changing, their expectations are increasing and their demands are becoming more complex. In particular, the desire to meet the needs of consumers in the market and to produce products and services suitable for the changes in their lives encourages businesses for innovation activities (Hippel, 2005: 46). The success of businesses depends on the full understanding of consumers' needs and desires and the participation of the first users of the products in the innovation process. Because the participation of consumers helps the business in the acceptance and adoption of the product in the market (Antikainen et al., 2010: 104). Businesses that develop a sustainable relationship with their customers can gain innovation skills by benefiting from the new ideas, opinions, and suggestions of consumers regarding their products and services. In a sense, this is an attempt to involve consumers in the innovation processes of businesses. According to Lettl et al. (2006), organizations must engage in an active, open and continuous dialogue with users, know how to 
manage users' differences, and involve users and their personalized experiences in the creation process. Although open innovation assumes that businesses can and should use outside ideas as well as internal ideas, user innovation assumes that users have sufficient motivation and knowledge to innovate and find solutions to their unmet needs for existing products/services (Chesbrough, 2003; Yiğit \& Aras, 2012). In order to benefit from users at the highest level possible in innovation activities, it is necessary to understand and manage how and at what stage users should be included in this process in the most effective way (Ilter, 2016: 36).

\subsection{Open Innovation}

Consumers are involved in all processes from production to distribution, except for the role of businesses in providing consumer needs information for determining consumer requests and needs. Consumers play an active role in any trouble and problem solving, new product and service development and innovation processes of businesses. This situation can be expressed as open innovation strategies that allow enterprises to benefit from outsourcing gain importance (İlter et al., 2016: 36). One of the most important actors in open innovation processes is customers (Piller and Walcher, 2006). In addition, businesses can integrate users into innovation processes by creating masses for the development of new products/services or solving any problem, and by taking advantage of the wisdom and collective intelligence of the masses. Nowadays, developments in information technologies, especially online tools, enable producer-consumer cooperation to increase in the new product development process and these technologies are used by businesses to involve users in the innovation process (İlter, et al., 2016: 36). The innovation approach, which is made by taking the ideas, opinions and suggestions of the stakeholders, groups, and users, is in a sense an open innovation approach. Open innovation is when an enterprise produces new ideas and applications with its internal resources, especially its own $R \& D$ activities, on the other hand, it continues its innovation activities by acquiring all kinds of new ideas, methods, workforce, and technology with external resources (Chesbrough et al., 2006). The open innovation paradigm admits that innovation-related businesses can/should use ideas outside the business as much as their own ideas. Open Innovation means that valuable ideas can come from inside or outside of the company and enter the market from inside or outside of the company (Chesbrough, 2006: 43). In this paradigm, innovation means the idea of innovations that enter the company through individuals or companies from outside. Crowdsourcing, or in other words, benefiting from the crowd, is the fact that businesses produce products/services and try to get the ideas, opinions and suggestions of individuals by making an open call to the masses they have determined in the marketing processes. Generally, such contributions are encouraged to be made free of charge or for a reasonable price (Kleeman et al., 2008; Yiğit and Aras, 2012). Gassmann and Enkel (2004) state open innovation as the collaborative creation of ideas and practices outside border of the a single firm. They describe open innovation processes as outside-in, inside-out and coupled.

Outside-in Process: With the integration of suppliers, customers and external information sources, the company can strengthen its innovation aspect by enriching its own knowledge base.

Inside-out Process: To present innovative ideas obtained from internal knowledge and innovation sources within the company to external users.

Coupled Process: It is the use of combining outside-in and inside-out approaches.

Chesbrough and Appleyard (2007) recommend that companies move from open innovation to "open strategy". Open strategy means open innovation, a balance between the need for businesses to generate profits and value creation and capture. Open innovation, in a sense, refers to user contributions based on users and the built-in momentum behind new ideas. Chesbrough and Appleyard (2007) identified four challenging areas to effectively manage open innovation processes in this context (Chesbrough and Appleyard 2007: 68);

- Ensuring the participation of a large group and to continue it within the specified time.

- Compete effectively for contributors in a world of limited supply.

- Determining the expectations regarding the participation of the users,

- Finding ways to profit from activities carried out in an open environment. 


\subsection{Outsourcing}

Outsourcing is a strategic management tool that allows the business to focus on the activities in which it has the core competency that gives it competitive advantage, and to provide the activities that do not fall within its own area of expertise and core competency through businesses outside the organization (Quinn et al., 1990: 60). Outsourcing is the procurement of products or services from external sources (Koçel, 1998). Businesses use outsourcing for purposes such as reduce costs, increase quality in products and services, increase business performance, reduce or spread risk, develop core capabilities, downsize, accelerate process renewal efforts, redistribute resources, follow technological innovations, globalization, restructuring, realizing lean production model, and to reduce competitive pressure (Saunders et al., 1997: 68). It is an outsourcing process for businesses to produce products and services that meet the demands and needs of consumers, to solve any problems or issues, or to create sustainable relationships with the masses and include them in the processes from production to distribution, making use of the ideas, opinions and suggestions of the masses.

\subsection{User-Generated Content}

User content, co-creation, and co-production are often seen as closely related to user innovation. Developments in Web 2.0 technologies have played a major role in the increase and sharing of usergenerated content. User content can be defined as media content created or produced by a specific audience, not by paid professionals and distributed mainly on the Internet (Daugherty et al., 2008: 19). User-generated content and crowdsourcing have regarded online system generally offered through social media websites or such as blogs, wikis, discussion forums, posts, chats, tweets, podcasts, digital images, video, audio files, advertisements which created by users of the service and other media formats (Moens et al., 2014). User-created content also used as consumer driven content which is defined as the new source type of online information that users create, become a member, disseminate and use in order to obtain information about products, brands, services, people, or areas of interest and to inform other users (Hüseyinoğlu, 2009: 84). User generated content, which can be defined simply as "the content of various types of media produced by the consumer, the end user", has three important features such as obligation to publish, creative effort, and independence from professional routines and practices (OECD, 2007: 17). In addition, user-generated content can be expressed as electronic wordof-mouth communication (eWOM) in terms of disseminating user-generated input via the online environment (Manap and Adzharudin, 2013).

\subsection{Consumer Creativity}

The product-oriented approach formed by dynamic marketing has left its place to the consumeroriented approach. Today's dynamic consumers are not just as buyers in the marketing process. They take a more active and effective role in product design and creation than branding. In this context, it has become much more important to include consumers in these processes with their innovative views and thoughts on design, product development, production, marketing and post-marketing processes, as well as listening, understanding, and knowing what they want. Web 2.0's two-way communication and interaction, content creation and simultaneous sharing, participatory and collaborative features have created a new type of consumer who is not afraid to use their creativity to offer innovations and improvements in products or services (Cova, 2008). While the masses created in social media are used for their creativity, innovative power and expertise, they benefit from low costs (Digout et al., 2013: 7). Consumer data is one of the most important and useful sources of idea generation for new product development. In today's technological developments and markets where competition is high, maintaining competitive advantage through new product development becomes more important especially for the survival and profitability of companies in the long run. Prosumer or co-creator concepts emphasize the creativity aspects of consumers. In this context, businesses that listen to their customers, evaluate their innovative ideas, include them in processes and offer value and use technologies and applications that support creative consumers effectively and efficiently in their marketing strategies will be one step ahead of the competition. 


\subsection{Co-creators}

Technological advances and the Internet have provided consumers with unlimited access to information and communication with other consumers and companies. Thus, consumers have been given a large role. An important consequence of this increased consumer empowerment is that consumers want to play a larger role in the residual value creation process. This process is called cocreation and can occur in various processes (Bolton and Saxena-Iyer 2009). In a sense, this is the cocreator role of the consumer, who produces identity, image, meaning, value, and experience in the marketplace through consumption practices (Dedeoğlu, 2015: 19). Co-creation is considered an important manifestation of customer loyalty behavior (Van Doorn et al., 2010). In particular, the cocreation activity of consumers is a new production development area. Consumers are willing and able to offer ideas for new goods or services that can meet needs not yet met by the market or improve existing offers (Ernst et al., 2010). They can easily send their ideas and thoughts to the company via websites, e-mails, and social networks. In this context, co-creation is defined as a collaborative activity in which consumers contribute actively in the process of developing a new product and service (O'Hern and Rindfleisch 2009: 4).

\subsection{Prosumers}

Technology has contributed to the transformation of the traditional passive consumer into a major source of creative talent. In other words, the consumer is involved in any stage of the production (design, content, quantity, etc.) of the product he consumes as a prosumer. One of the most important results of the Internet and Web 2.0 technology has been the participation of users in the production process. This increased participation has greatly contributed to the development of active, participatory, collaborative, and interactive social media tools, especially with the bidirectional and simultaneous information sharing offered by Web 2.0 technology. Users can create and share content using Web 2.0 technology supported channels (Facebook, Instagram, Flickr, Twitter). As users both consume and produce content, it blurs the line between consumption and production activities (Berthon et al., 2008). Web 2.0 technology has transformed individuals not only as consumers, but also as consumers who produce them. Prosumers tend to take part in any part of the process until the product/service they consume is offered to them, they question, research, recommend, define themselves through the product or service they consume, and create value. Thus, the prosumers which the consumers of the postmodern age become a part of production by generating value and experience (Şahin, 2016: 2). There is a process of creating value together between businesses and prosumers in the sharing economy. Prosumers have begun to have multiple roles and tasks by sharing their products, services or skills. On the other hand, the co-creation behavior of prosumers has become more widespread and more important than traditional business models (Ayazlar, 2018: 1189).

\subsection{Open Source}

The emergence of the crowdsourcing movement can be regarded as the beginning of the free software movement. Open source is a development model that encourages the design and plans of a product to be accessible to everyone without restrictions, and the re-sharing of the design or plan, including third parties, by making changes (Gerber et al., 2010). Crowdsourcing is the application of open source principles to areas other than software (Howe, 2008). Open Source practices have shown that communities have the potential to be more successful than company employees. The main claim here is that the person who will do a job best is the one who wants to do it the most (Aktaş, 2019: 269). Open source applications are used extensively in the design and testing stages of the product development process. Many successful computer applications such as Apache, Linux, and Firefox are open source applications managed by virtual communities created by their own organizations (O'Hern \& Rindfleisch, 2008).

\subsection{Wisdom of Crowd and Collective Intelligence}

The development and spread of Web 2.0 technology and social media channels has contributed to the formation of large and scattered groups of people and to the development of the concept of common mind by making it easier for members to communicate and interact with each other. 
According to Krause et al. (2009), collective intelligence is the acquisition of information by two or more individuals independently or at least partially independently and the processing of these different information packages by combining them through social interaction. Common intelligence can generally be defined as cognitive abilities obtained as a result of communication between members or representatives of a community. The concept is defined by Levy (1997: 13) as "the universal mind that is coordinated in real time and results in an effective activation of skills". It is the idea that the crowds make superior decisions than individuals regarding the wisdom and collective intelligence of the crowd (Surowiecki, 2004). Surowiecki described in four features of affecting the collective intelligence of crowds; diversity (each person has his/her own knowledge), independence (individuals' ideas are not affected by each other), decentralization (individuals' knowledge is locally focused), and integration (subjective information turns into a common decision) (Surowiecki, 2004: 13). The masses can make superior decisions under certain conditions. The most important feature of crowdsourcing is to create suitable and special conditions for the crowds for high quality information that creates value.

\section{Digital Consumer Behavior}

While today is drifting from modernization to post-modernization, consumption behaviors are also changing (Akçal1, 2013: 80). Developments in information communication technologies and technological devices have made consumers an information user and an information source that benefits from the wisdom or collective intelligence of the masses in terms of businesses, with a consumer culture that aims to maximize the benefits of technology. Social trends driven by the digital revolution are changing consumer behaviors and demands. It is expected to continue to do so. Digital consumer behavior is about how consumers experience, influence and are affected by the digital environments they are in as part of their daily lives. The new generation of consumers, who have more information about products and companies, increase their communication and interaction with other consumers, compare brands not only with their competitors, but with all other companies regardless of the sector or product, show less tolerance, complain very quickly and find it difficult to be satisfied. They have become so effective that they become stronger or weaker (Hughes, 2016). When brands cannot meet these high expectations of consumers, consumers share their negative experiences with others on digital platforms. Stephen (2016) stated issues affecting consumer behavior in digital and social media marketing environments (i) consumer digital culture, (ii) responses to digital advertising, (iii) effects of digital media on consumer behavior, (iv) mobile environments, and (v) online word of mouth communication (WOM). Hughes (2016) describes the demands of the new generation of consumers as convenience, consistency, timeliness, and communication as well as being heard and real-time fulfillment. According to Kapoor (2015), consumers value speed, simplicity, quick answers to questions and reliable delivery, rather than worrying about whether they are shopping online or instore.

\section{Crowdsourcing User Behavior and Challenges}

The rapid developments in information and communication technologies have removed the constraints related to the concepts of time, space, and speed. These developments have created a network society system that surrounds consumer-oriented individuals, which allows easy access to information, creating community and content, sharing information, comments and experiences, and socializing with two-way communication and interaction. In this digitalized environment, individuals carry out almost all their transactions over the internet with computers and mobile/smart devices. The web, which includes large stores, offers the opportunity to be reached at any time and from anywhere, product variety, comparison, making/reading comments about products, communicating with sellers and delivering to their addresses. The development of internet and web 2.0 technology and the new media that have emerged in parallel with this have turned into a kind of collaborative situation where consumers are involved in almost all processes of organizations by taking information, ideas, opinions, and suggestions. The increase in the use of internet and social media tools has enabled manufacturers to create more collaborative consumers. The consumer, which takes place in all marketing processes of businesses, has also been the source of innovative and creative ideas. However, the selection of the crowds created online, determining their size and motivation issues also emerge as important problems. In this context, it is an important issue to know the behavior of crowdsourcer in the value creation process. Knowing the crowdsourcer's behavior will provide benefits in terms of mobilizing 
consumers, reducing the time spent in new product development, increasing the acceptance of the new product in the market, and improving the consumer's subjective perception of innovation. In addition, crowdsourcing contributes to reaching more qualified audiences, providing more qualified information, and obtaining easy and cost-effective feedback. Audience engagement in online social platforms can be increased through crowdsourcing, but it can also create an environment where users are motivated by various activities as sole creators and promoters of product marketing. In addition to the determination, selection and size of the audience to be created online, knowing the behavior of this audience and the tools to motivate them is an important issue for businesses. In this context, a willing, active and motivated crowd, transparency and trust of participants, and not manipulating crowdsourcing practices, or using participatory culture as exploitation play an important role in the success of organizations that will perform crowdsourcing. In addition, there are six ways to increase user participation in online communities: getting information, giving information, building reputation, developing relationships, entertainment and self-discovery (Khan, 2017: 238). Participation in crowdsourcing is driven by the motives of the individual. In crowdsourcing, intrinsic motivators may arise from an individual's innate feelings of desire, a sense of competence, satisfaction, and pleasure, while the potential to earn a reward for participation can function as an external stimulus (Leimeister, 2009). Extrinsically activated motives are expressed as direct compensatory and social motives (Vallerand, 1998). Social motives include the expected response of individuals whose ideas are valued by the participant, such as friends, partners, or spectators. According to (Roth et al., 2015: 19), the motivation of individuals in the crowdsourcing method is divided into three areas. These are;

Intrinsic Impulses: playful tasks,

Internalized External Impulses: Self-efficacy, desire to raise status and be visiblerecognizable, make friends, gain knowledge, and develop talents,

External Impulses: In addition to eliminating income gap, personal needs and dissatisfaction impulses.

Brabham (2013: 68) stated the motivations of crowdsourcing participants as earning money, developing creative skills, reaching other creative professionals, creating a portfolio for the purpose of finding a job in the future, challenge yourself by solving a difficult problem, socializing and making friends, spending time, participating in projects of common interest, sharing, and enjoying. Wasko and Faraj (2000) point out that the main motivation for engaging in online stages is to help the group. Brabham (2008a) revealed addiction as the motivation to engage in the online phase. Antikainen et al., (2010) state that the combination of collaborative energy and thoughts is a vital motivation factor. The success of the crowdsourcing phase largely depends on the individuals and their inspiration to engage. Inspiration decides the quality and quantity of commitments (Janzik, 2010). In addition, when the importance of the event is explained to the participants in detail, it will increase the motivation of the individuals to participate in the competitions. According to Groves et al. (2000), participation in a study with the community has a positive effect on individual cooperation and participation. In addition, crowdsourcing participants can expect positive responses from other participants, organizers, or beneficiaries of the event. Information asymmetry between companies and users is another important issue. A solution is proposed using signal theory to solve the information asymmetry problem. Signal theory is mainly concerned with reducing the information asymmetry between the two parties (Spence, 2002). Bad reputation, entertainment and mental self-view etc. are other important explanations behind individuals' interest in online stages (Antikainen, 2010; Davenport, 2005). Gao et al. (2021) stated that online reputation and price comparison positively affects user engagement behavior and that interpersonal trust has a strong mediating effect on the relationship between wages and user engagement behavior. Another issue to increase users' participation in crowdsourcing is rewards. The award is an external form of motivation to increase participation in virtual communities (Horng, 2017). 


\section{Evaluation and Conclusion}

The development of Internet and WEB technologies has increased the easy accessibility of information anytime and anywhere, providing the opportunity to establish two-way communication, make comments, create a community, and share by producing content. In a sense, this is the success of Web 2.0, which is also expressed as the social web that allows socialization. Paniagua and Sapena (2014) state that social media increases business performance in four areas: social capital, customer preferences, social marketing and social corporate networking. Social media channels offer many advantages to businesses in terms of knowing the wishes and needs of individuals, getting ideas and suggestions about new product and service development and innovation. Crowdsourcing practices, which are widely used in the context of marketing, new product development, new advertising theme and message research, new product market test research, marketing research, various word-of-mouth marketing (WOM) research, content creation and feedback can be given as examples (Whitla, 2009). Businesses, on the other hand, include the target audience or users they have determined in all processes from product design to distribution. Thus, they both establish a sustainable relationship and realize innovation by taking their ideas and suggestions about solving any problem or innovation. In this context, the masses are benefited from by taking their ideas, opinions, and suggestions through an open call to the determined masses over the internet. Crowdsourcing provides online communities with suggestions for products/services, social questions and answers, and content crowdsourcing contributor through competitions where users produce their own videos, share images, and blog interactions. Crowdsourcing is a strategic marketing tool for content creation, idea generation, product development, customer insights, customer engagement, customer loyalty, and pricing. In addition, crowdsourcing used in advertising, promotion, product development and market areas is the best example of getting qualified feedback from expert personnel at low cost. Digital consumers or users who transform new ideas into crowdsourcing are also sources of innovation for businesses. In addition, the increase in mobile tools and mobile-based online social applications causes an increase in the number of online resource users.

Various search engines and apps have become major drivers of mobile devices used for crowdsourcing and online community engagement. Among the widely known ones are Amazon Mechanical Turk (MTurk), SurveyMonkey, CrowdFlower, Cualtricks, CrowdComputing Systems, CrowdSource, MobileWorks, Upwork, ChinaCrowd, gMission, ConcerseGallery, ClickWorker, oDesk, iPhone Apps, Facebook, Twitter (Altunıșık, 2017: 977). Crowdsourcing, which contributes in different areas such as problem solving, learning, open innovation, new product development and collaborative initiatives, has recently become an outsourcing use that organizations frequently use. These developments offer businesses great advantages in new product development and innovation. By activating users in the value creation process, new products can be developed with the information obtained from their collective intelligence. In this context, it is important in terms of reducing new product development time, innovation costs, and increasing the acceptance of new products and services in the market. However, the most important problems are how to determine the audience that will add value, its breadth, participation and their motivation. Subjects such as willingness, interest, cooperation, detailed expression, transparency, trust, reward, reputation, and reducing information asymmetry will contribute to the motivation of mass individuals. It is important factors in the success of crowdsourcing that businesses benefit from the wisdom of the crowds, taking into account issues such as a willingess, active and motivated crowd, transparency and trust of participants in each other, and not manipulating crowdsourcing practices or using participatory culture as exploitation. The effective and efficient use of the crowd in the processes of solving any problem or trouble, developing new products/services or making innovations will provide many advantages to the organizations in an intense competitive environment. In this direction, businesses will be able to reach their goals with the selected audiences. 


\section{References}

Akçalı, S.İ. (2013). Dönüşen kent ve yaşam biçimleri: yeni yaşam mekânları bağlamında geç kapitalizmi okumak. Akademik Araştırmalar Dergisi, 57, 77-94.

Aktaş, S. (2019). Kitlelerin çevrimiçi ortamlarda sanat üretimine katılımı ve kitle kaynak uygulamaları: Transformers premake. Uludağ Üniversitesi Fen-Edebiyat Fakültesi Sosyal Bilimler Dergisi, 20(36), 259-286. https://doi.org/10.21550/sosbilder.456718.

Alan, A.K., Kabadayı, E.T \& Erişke, T. (2018). İletişimin yeni yüzü: Dijital pazarlama ve sosyal medya pazarlama. Elektronik Sosyal Bilimler Dergisi, 17(66), 493-50. https://doi.org/10.17755/esosder.334699.

Alharthi, A., Krotov, V. \& Bowman, M. (2017). Addressing barriers to big data. Business Horizons, 60(3), 285-292. https://doi.org/10.1016/j.bushor.2017.01.002.

Altınbaşak İ. ve Karaca E. S. (2009). İnternet reklamc1lığı ve internet reklam ölçümlenmesi üzerine bir uygulama. Ege Akademik Bakış, 9, 463-487.

Altunışık, R. (2017). Bir veri toplama platformu olarak crowdsourcing (CS): Mechanical Turk örneği üzerinden bir literatür taraması ve değerlendirme. Uluslararası Yönetim İktisat ve İsletme Dergisi, ICMEB17 Özel Say1s1, 975-982. https://doi.org/10.17130/ijmeb.2017ICMEB1735504.

Antikainen, M., Makipaa, M. \& Ahonen, M. (2010). Motivating and supporting collaboration in open innovation. European Journal of Innovation Management, 13(1), 100-119. https://doi.org/10.1108/14601061011013258.

Arolas, E. \& Guevara, G.L. (2012). Towards an integrated crowdsourcing definition. Journal of Information science, 38(2), 189-200. https://doi.org/10.1177/0165551512437638.

Ayazlar, R. A. (2018). Paylaşım ekonomisi ve turizm endüstrisine yansımaları. Gaziantep University Journal of Social Sciences, 17(3), 1185-1202. https://doi.org/10.21547/jss.376826.

Bakić, T. V., Kostić, S. C. \& Nešković, E. (2014). Application of crowdsourcing in marketing. Marketing Managment, 1079, 1087.

Berthon, P., Pitt, L. \& Campbell, C. (2008). Ad lib: When customers create the ad? Calif. Manage. Rev, 50 (4), 6-30. https://doi.org/10.2307/41166454.

Berthon, P. R., Pitt, L. F., Plangger, K. \& Shapiro, D. (2012). Marketing meets web 2.0, social media, and creative consumers: Implications for international marketing strategy. Business Horizons, 55, 261-271. https://doi.org/10.1016/j.bushor.2012.01.007.

Bolton, Ruth N. \& Shruti Saxena-Iyer (2009). Interactive services: A framework, synthesis and research directions. Journal of Interactive Marketing, 23 (1), 91-104. https://doi.org/10.1016/j.intmar.2008.11.002.

Brabham, D.C. (2008a). Moving the crowd at IStockphoto: The composition of the crowd and motivations for participation in a crowdsourcing application. First Monday, 13(6), 1-22. https://doi.org/10.5210/fm.v1316.2159.

Brabham, D. C. (2008b). Crowdsourcing as a model for problem solving: An introduction and cases. The International Journal of Research into New Media Technologies. 14(1): 7590. https://doi.org/10.1177/1354856507084420.

Brabham, D. C. (2013). Crowdsourcing. Cambridge, Massachusetts; London, England: The MIT Press.

Büyükpilavc1, C. (2014). Kitlesel fonlamanın ürün tasarımcıları için sunduğu firsatlar: Türkiye'deki kitlesel fonlama platformlarl üzerine bir inceleme. Yüksek Lisans Tezi, İstanbul Teknik Üniversitesi Fen Bilimleri Enstitüsü. İstanbul. 
Chen, Y., Wang, Q. \& Xie, J. (2011). Online social interactions: a natural experiment on word of mouth versus observational learning. Journal of Marketing Research, 48(2), 238-254. https://doi.org/10.1509/jmkr.48.2.238.

Chesbrough, H. (2003). Open innovation: The new imperative for creating and profiting from technology. Boston: Harvard Business School Press.

Chesbrough, H., Vanhaverbeke, W. \& West, J. (Eds.). (2006). Open innovation: Researching a new paradigm. Oxford University Press on Demand.

Chesbrough, H. M. \& M. Appleyard. (2007). Open innovation and strategy. California Management Review, 50: 57-76.

Conrad, J., Levinson, J., \& Gibson, S. (2010). Guerrilla social media marketing. Irvine, CA: Entrepreneur Press.

Cova B. (2008). Consumer Made, Quand le consommateur devient producteur, Décisions Marketing Paris, 50(2008), 19-27. https://doi.org/10.2307/20723307.

Daugherty, T., Eastin, M. \& Bright, L. (2008). Exploring consumer motivations for creating usergenerated content. Journal of Interactive Advertising, 8(2), 1-25. https://doi.org/10.1080/15252019.2008.10722139.

Davenport, T.H. (2005). The coming commoditization of processes. Harvardbusiness Review, June.

Dawson, R. \& Bynghall, S. (2011). Getting results from crowds: The definitive guide to using crowdsourcing to grow your business. San Francisco: Advanced Human Technologies Inc.

Dedeoğlu, A.Ö. (2015). Değişen pazaryerinde tüketici ve tüketimin rolüne ilişkin yeni yaklaşımlar: Ortak-üretim (co-production) ve ortak-yaratma (co-creation). Ege Strategic Research Journal, 6 (2), 17-29. https://doi.org/10.18354/esam.75360.

Digout, J., Azouri, M., Decaudin, J.M., \& Rochard, S. (2013). Crowdsourcing, outsourcing to obtain a creativity group. Arab Economic and Business Journal, 8(1/2), 6-15. http://dx.doi.org/10.1016/j.aebj.2013.11.001.

Ernst, H., Wayne D. Hoyer, M.K. \& Jan-Henrik, S. (2010). Consumer idea generation. Working Paper, WHU, Vallendar.

Gao, S., Jin, X. \& Zhang, Y. (2021). User participation behavior in crowdsourcing platforms: Impact of information signaling theory. Sustainability, 13(1), 1-19. https://doi.org/: $10.3390 / \mathrm{su} 13116290$.

Gassmann, O. \& Ellen, E. (2004). Towards a theory of open innovation: Three core process archetypes. Proceedings of the RADMA Conference.

Gatautis, R. \& Vitkauskaite, E. (2014). Crowdsourcing application in marketing activities. Procedia Social and Behavioral Sciences, 110, 1243-1250. https://doi.org/: 10.1016/j.sbspro.2013.12.971.

Gerber, A., Molefo O. \& Van der Merwe, A. (2010). Documenting open source migration processes for re-use. Proceedings of the SAICSIT 2010 Conference- Fountains of Computing Research, ACM Press, $75-85$.

Gnizy, I. (2019). Big data and its strategic path to value in international firms. International Marketing Review, 36(3), 318-341. https://doi.org/10.1108/IMR-09-2018-0249.

Groves, R. M., Singer, E. \& Corning, A. (2000). Leverage-salience theory of survey participation. Public Opinion Quarterly, 64 (3), 299-308. https://doi.org/10.1086/317990.

Hippel, E. (1988). The sources of innovation. New York: Oxford University Press.

Horng, S.M. (2016). A study of active and passive user participation in virtual communities. Journal of Electronic Commerce Research, 17(4), 289-311. 
Howe, J. (2006). The rise of crowdsourcing. Wired. 14(6), 1-5.

Howe, J. (2008). Crowdsourcing: Why the power of the crowd is driving the future of business. New York: Crown Business.

Hughes, A. (2016). How the digital revolution is changing consumer behaviour. PA: http://www.paconsulting.com/our-thinking/how-the-digital-revolution-is-changingconsumerbehaviour/ (Erişim Tarihi: 19.06.2021).

Hüseyinoğlu, Beyza (2009) Tüketici tarafindan yaratılan medya ortamında ă̆ızdan ă̆ıza pazarlama ve bir uygulama. Yüksek Lisans Tezi, Yıldız Teknik Üniversitesi Sosyal Bilimler Enstitüsü İşletme Anabilim Dalı, İstanbul.

İlter, B., Atrek, B. \& İpek, İ. (2016). İnovasyon faaliyetlerinde kullanıcının yeri ve çevrimiçi kullanıcı inovasyon araçları. Yönetim ve Ekonomi Dergisi, 23(1), 35-56. https://doi.org/: 10.18657/yecbu.85726.

Janzik, L. (2010). Contribution and participation in innovation communities: A classification of incentives and motives. International Journal of Innovation and Technology Management, 7(3), 247-262. https://doi.org/10.1142/S0219877010002021.

Kabani, S., \& Brogan, C. (2010). The zzen of social media marketing. Dallas, TX: Benbella Books.

Khan, M.L. (2017). Social media engagement: what motivates user participation and consumption on youtube? Computers in Human Behavior, 66(2017), 236-247. https://doi.org/10.1016/j.chb.2016.09.024.

Kaplan, A. M. \& Haenlein, M. (2010). Users of the world, unite! the challenges and opportunities of social media. Business Horizons, 53(1), 59-68. https://doi.org/10.1016/j.bushor.2009.09.003.

Kapoor, M. (2015). Creating a seamless retail customer experience. The Economist Intelligence Unit.

Kılıç, Ç. (2015). Gündem belirleme kuramı çerçevesinde siyasal karar verme sürecine sosyal medya etkisinin incelenmesi. Yüksek Lisans Tezi. İstanbul Ticaret Üniversitesi Sosyal Bilimler Enstitüsü, İstanbul.

Kleemann, F., Voss, G., \& Rieder, K. (2008). Un(der)paid innovators: The commercial utilization of consumer work through crowdsourcing. Science, Technology \& Innovation Studies, 4(1), 5- 26. https://doi.org/10.17877/DE290R-12790.

Koçel, T. (1998). İsletme yöneticiliği. İstanbul: Beta Basım Yayım Dağıtım A.Ş.

Krause, J., Ruxton, G. \& Krause, S. (2009). Swarm intelligence in animals and humans. Trends in Ecology and Evolution, 25(1), 28-34. https://doi.org/10.1016/j.tree.2009.06.016.

Leimeister, J. M., Huber, M., Bretschneider, U. \& Krcmar, H. (2009). Leveraging crowdsourcing: Activation supporting components for it-based ideas competition. Journal of Management Information Systems (JMIS), 26(1), 197-224. https://doi.org/10.2753/MIS0742-1222260108.

Lettl, C., Cornelius, H. \& Gemuenden, H.G. (2006). Users contributions to radical innovation: Evidence from four cases in the field of medical equipment technology. $R \& D$ Management, 36(3), 251-272. https://doi.org/10.1111/j.1467-9310.2006.00431.x.

Levy, P. (1997). Collective intelligence: Mankind's Emerging World in Cyberspace. Trans. Robert Bononno, Cambridge: Perseus Books.

Libai, B., Bolton, R., Bugel, M. S., de Ruyter, K., Gotz, O., Risselada, H. \& Stephen, A. T. (2010). Customer-to-customer interactions: Broadening the scope of word of mouth research. Journal of Service Research, 13(3), 267-282. https://doi.org/10.1177/1094670510375600.

Manap, K. H. A., \& Adzharudin, N. A. (2013). The role of user generated content (UGC) in social media for tourism sector. In West East Institute International Academic Conference Proceedings, Istanbul, Turkey. 
Moe, W. W. \& Schweidel, D. A. (2017). Opportunities for innovation in social media analytics. Journal of Product Innovation Management, 34(5), 697-702. https://doi.org/10.1111/jpim.12405.

Moens, M. F., Li, J., Chua, T. S. (2014). Mining user generated content. New York, USA: CRC Press, Taylor \& Francis Group.

Nair, H. S., Manchanda, P. \& Bhatia, T. (2010). Asymmetric social interactions in physician prescription behavior: The role of opinion leaders. Journal of Marketing Research, 47(5), 883895. https://doi.org/10.1509/jmkr.47.5.883.

OECD. (2007). Participative web and user-created content web 2.0, wikis and social networking. Paris: OECD.

O'Hern, M. S., Rindfleisch A. (2008). Customer co-creation: A typology and research agenda. working paper 4, Wiscons innovation thoughts on innovation from the Wisconsin School of Business.

O'Hern, Matthew S. and Aric Rindfleisch (2009). Customer co-creation: A typology and research agenda, in review of marketing research, Vol. 6, Naresh K. Malholtra, ed. Armonk, NY: M.E. Sharpe, 84-106.

Quinn, J. B., Doorley, T. L. \& Paguette, P. C., (1990). Beyond products: Services-based strategy. Harvard Business Review, 60, March-April.

Palacios, M., Martinez-Corral, A., Nisar, A. \& Grijalvo, M. (2016). Crowdsourcing and organizational forms: Emerging trends and research implications. Journal of Business Research, 69(5), 18341839. https://doi.org/10.1016/j.jbusres.2015.10.065.

Paniagua, J. \& Sapena, J. (2014). Business performance and social media: Love or hate? Bus Horiz. 57(6), 719-28. https://doi.org/10.1007/978-1-4614-6616-1_200009-1.

Peters, K., Chen, Y., Kaplan, A. M., Ognibeni, B. \& Pauwels, K. (2013). Social media metrics: A framework and guidelines for managing social media. Journal of Interactive Marketing, 27(4), 281-298. http://dx.doi.org/10.1016/j.intmar.2013.09.007.

Piller, F. T., Walcher D. (2006). Toolkits for idea competitions: A novel method to integrate users in new product development. $R \& D$ Management, 36 (3), 307-318. https://doi.org/10.1111/j.14679310.2006.00432.x.

Prahalad, C.K. \& Ramaswamy, V. (2000). Co-opting customer competence. Harvard Business Review, 79-87.

Prpić, J., \& Shukla, P. (2016). Crowd science: Measurements, models, and methods. In Proceedings of the 49th Annual Hawaii International Conference on System Sciences, Kauai, Hawaii: IEEE Computer Society.

Roth, Y., Brabham, D.C., Lemoine, J.F. (2015). Recruiting individuals to a crowdsourcing community: Applying motivational categories to an ad copy test. In Fernando J. GarrigosSimon, Ignacio Gil-Pechuán ve Sofia Estelles-Miguel (Ed.), Advances of Crowdsourcing (1532). Cham: Springer.

Sánchez, D. Á., Gimilio, D. P. \& Altamirano, I. J.. (2015). Crowdsourcing: a new way to citizen empowerment. en advances of crowdsourcing, 73-86, Cham: Springer.

Saunders, C., Gebelth, M. and Hu, Q., (1997). Achieving success in information systems outsourcing. California Management Review, 39 (2), 64-68. https://doi.org/10.2307/41165887.

Saxton, G.D., Oh, O., \& Kisher, R. (2013). Rules of crowdsourcing: Models, issues and systems of control. Information Systems Management, $30,20$. https://doi.org/10.1080/10580530.2013.739883.

Şeker, S.E. (2015). Kitle kaynak (crowd sourcing), YBS Ansiklopedi, 2, 6-11. 
Spence, M. (2002). Signaling in retrospect and the informational structure of markets. Am. Econ. Rev. 92, 434-459. https://doi.org/10.1257/00028280260136200.

Stephen, A.T. (2016). The role of digital and social media marketing in consumer behavior. Psychology special issue on consumer behaviour. Current Opinion in Psychology, 10(1), 1-16. https://doi.org/10.1016/j.copsyc.2015.10.016.

Surowiecki, J. (2004). The wisdom of crowds: why the many are smarter than the few and how collective wisdom shapes business. Economies, societies and nations. Randomlarge House Print, New York, Usa.

Şahin, N.N. (2016). Evaluating the consumption patterns of prosumers in food and beverage sector by the scale of the values and lifestyles system. Master thesis, Balıkesir University Social Sciens Institute The Department of Tourism and Hotel Management.

Tong, Y., Zhou, Z., Zeng, Y. \& Chen, L. (2000). Spatial crowdsourcing: A survey. The VLDB Journal, 29, 217-250. https://doi.org/10.1007/s00778-019-00568-7.

Vallerand, R.J. \& Fortier, M.S. (1998). Measures of intrinsic and extrinsic motivation in sport and physical activity: A review and critique. In J.L. Duda (ed.), advances in sport and exercise psychology measurement. Morgantown, WV: Fitness Information Technology, pp. 81-101.

Van Doorn, Jenny, Katherine N. Lemon, Vikas Mittal, Stephan Naß, Doree'n Pick, Peter Pirner, \& Peter Verhoef (2010). Customer engagement behavior: Theoretical foundations and research directions. Journal of Service Research, 13(3), 253-266. https://doi.org/10.1177/1094670510375599.

Wasko, M. \& Faraj, S. (2000). It is what one does: why people participate and help others in electronic communities of practice. Journal of StrategicInformation Systems, 9(2-3), 155-73. https://doi.org/10.1016/S0963-8687(00)00045-7.

Weinberg, T. (2009). The new community rules: Marketing on the social web. First edition. Sebastopol: O'Reilly Media

Whitla, P. (2009). Crowdsourcing and its application in marketing activities. Contemporary Management Research, 5, 15- 28. https://doi.org/10.7903/cmr.1145.

Yiğit, S. \&Aras M. (2012). Crowdsourcing as a tool of open innovation and applicability in universities - sample case of feas in Gaziosmanpaşa University. Suleyman Demirel University The Journal of Faculty of Economics and Administrative Sciences, 17 (3), 485-508. 